\title{
Evaluation of algal regulation by herbivorous fishes on Caribbean coral reefs
}

\author{
Dorothée Kopp • Yolande Bouchon-Navaro • \\ Sébastien Cordonnier · Alexandre Haouisée · \\ Max Louis • Claude Bouchon
}

Received: 4 March 2009/Revised: 7 October 2009/Accepted: 19 October 2009/Published online: 6 November 2009

(C) Springer-Verlag and AWI 2009

\begin{abstract}
The role of herbivorous fishes in maintaining low macroalgal cover was evaluated on coral reefs on several reef sites from Guadeloupe, either protected or not. Grazing by herbivorous fishes was assessed on different algal facies using fish-bite counts. Algal consumption by fish was estimated as well as algal production. Bite counts revealed that herbivorous fishes feed preferentially on algal turf and avoid brown macroalgae. The algal consumption varied between 0.4 and $2.8 \mathrm{~g} \mathrm{~m}^{-2}$ days $^{-1}$ and was higher inside marine protected areas than outside. Comparison with algal production revealed that herbivorous fishes did not succeed in regulating algal growth. The insufficient number of grazers may lead to the dominance of stable assemblages of macroalgae on coral reefs, preventing the recovery of reef into previous coral-dominated ecosystems.
\end{abstract}

Keywords Algal consumption · Caribbean · Coral reefs · Herbivorous fishes $\cdot$ Herbivory pressure

\section{Introduction}

The widespread degradation of coral reefs and the shift from scleractinian coral-dominated towards macroalgaedominated communities have been documented worldwide (Jackson et al. 2001; Gardner et al. 2003; Pandolfi et al.

Communicated by A. Malzahn.

D. Kopp $(\bowtie) \cdot$ Y. Bouchon-Navaro · S. Cordonnier .

A. Haouisée · M. Louis · C. Bouchon

DYNECAR, Laboratoire de Biologie Marine,

Université des Antilles et de la Guyane,

Pointe-à-Pitre, 97159 Guadeloupe, France

e-mail: dkopp@univ-ag.fr
2003, 2005; Bellwood et al. 2004, 2006; Hughes et al. 2003, 2007). Although Pandolfi et al. (2003) have pointed out that coral reefs have been degraded since the 1900 s mainly from overfishing, it is widely accepted that the coral-algal shift has been accelerating in the recent years. The causes are multiple and can be from natural or anthropogenic origins (hurricanes, global warming, eutrophication, overfishing, pollution, increased sedimentation). Crustose coralline algae and algal turfs are a common component of healthy coral reefs, but nowadays, the decline of coral communities is associated to a proliferation in erect macroalgae cover (Pandolfi et al. 2003).

This shift in dominance of benthic organisms affects the Caribbean reefs where benthic communities, originally dominated by invertebrates (corals, sponges, gorgonians) associated with algal turf, are now often replaced by macroalgae (Hughes 1994). According to Gardner et al. (2003), a dramatic drop in coral cover has occurred across the Caribbean from 50 to $10 \%$ in the past three decades. In the French West Indies (F.W.I.), remote sensing of marine coastal ecosystems showed that only $15-20 \%$ of coral reef ecosystems are still flourishing, i.e. presenting a high rate of living coral spectral response (Chauvaud et al. 1998, 2001). The degradation of these coral reefs began in the 1950s (Bouchon and Laborel 1986, 1990) and nowadays the percentage of necrosed tissues on coral colonies is varying between 11 and $56 \%$ according to reef sites (Bouchon et al. 2008a). Coral cover has declined and algal communities have supplanted coral communities with dominant brown macroalgae such as Dictyota, Lobophora and Sargassum (Bouchon et al. 2008b). In this context, there is an urgent need to determine which ecological processes may limit algal pressure on coral reefs and, more particularly, what is the ability of grazing organisms to control this proliferation. 
Previous studies have shown that, on coral reefs, herbivorous organisms consume a large part of algal productivity (Hatcher 1981; Carpenter 1986; Paddack et al. 2006). Through their role in algal removal, these herbivores are essential for coral reef resilience and reef recovery towards coral dominated states (Mumby et al. 2006). However, the increasing catch of herbivorous fishes has resulted in depletion of grazing pressure and hence, by cascade, increased proliferation of algae (Jackson et al. 2001; Mumby 2006). Indeed, in many locations grazers are no longer present in sufficient numbers and biomass to limit and control algal growth, thus leading to the expansion of macroalgae to the detriment of scleractinian corals.

In this study, we propose to quantify algal consumption by fish as well as algal production on different reefs to test whether herbivorous fishes have an influence on algal communities and how they may influence the stability of coral reefs.

\section{Materials and methods}

Study area

Guadeloupe Island is located in the Lesser Antilles (Fig. 1). It is composed of two islands, Grande-Terre and
Basse-Terre separated by a narrow channel called "Rivière Salée". Eleven reefs sites were studied around the island: six were located on barrier and fringing reef flats at one metre depth and five were situated on reef slopes between 10 and $15 \mathrm{~m}$ (Fig. 1). Four reef flats (S1, S2, S3, S4) are submitted to human influence (urban pollution, trap fishing, spear fishing, etc.). The two other reef flats are located inside protected areas (S5, S6) where fishing has been forbidden since 1979 and 1987 respectively. Three of the studied reef slopes are located inside MPA (S7, S8, S9), and two others (S10, S11) are submitted to urban pollution and heavy fishing.

Fish surveys

Estimates of fish abundances, both in density and biomass, were carried out on each reef site and obtained from a $150 \times 2 \mathrm{~m}$ transect. Each transect was replicated two times at each site. All species of Scaridae and Acanthuridae present on the coral reefs of Guadeloupe were studied: Scarus iserti Bloch, 1789, Scarus taeniopterus Desmarest, 1831, Scarus vetula Bloch and Schneider, 1801, Sparisoma aurofrenatum (Valenciennes, 1840), Sparisoma chrysopterum (Bloch and Schneider, 1801), Sparisoma rubripinne (Valenciennes, 1840), Sparisoma viride (Bonnaterre, 1788), Acanthurus bahianus

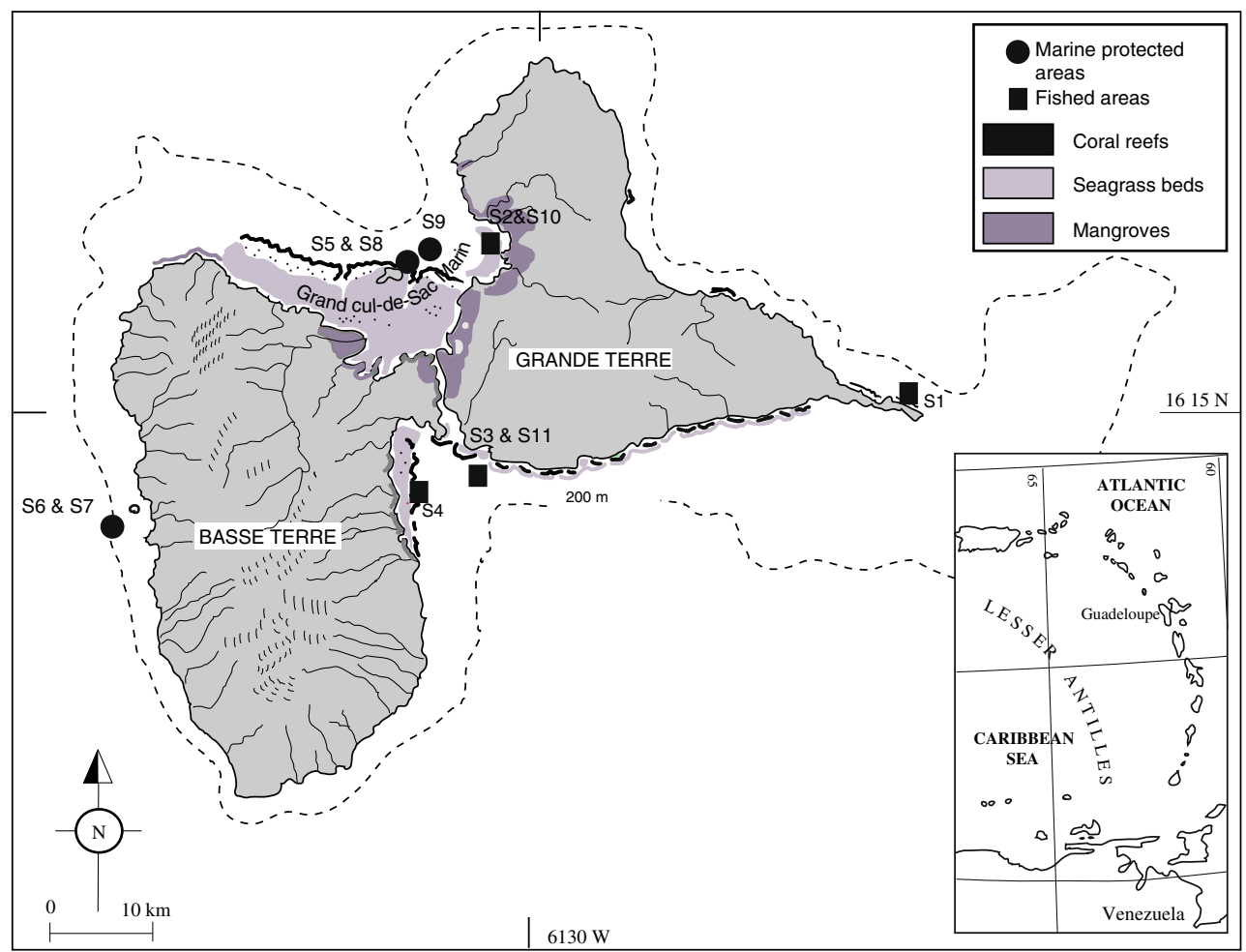

Fig. 1 Map of the Guadeloupe Island and location of the studied sites (S1-S11) 
Table 1 Parameters of the weight-length relationship with $a$ : coefficient and $b$ : exponent

Values for Sparisoma viride were used for Scarus vetula as no data is available in the literature

\begin{tabular}{llll}
\hline Species & $a$ & $b$ & Source \\
\hline Scarus iserti & 0.0166 & 3.0200 & Claro and García-Arteaga (1994) \\
Scarus taeniopterus & 0.0176 & 2.9990 & Bouchon-Navaro (1997) \\
Scarus vetula & 0.0251 & 2.9214 & cf Sparisoma viride \\
Sparisoma aurofrenatum & 0.0301 & 2.8184 & Bouchon-Navaro (1997) \\
Sparisoma chrysopterum & 0.0229 & 2.8801 & Bouchon-Navaro (1997) \\
Sparisoma rubripinne & 0.0474 & 2.6824 & Bouchon-Navaro (1997) \\
Sparisoma viride & 0.0251 & 2.9214 & Bohnsack and Harper (1988) \\
Acanturus bahianus & 0.0203 & 2.9281 & Bouchon-Navaro (1997) \\
Acanthurus chirurgus & 0.0183 & 3.0129 & Bouchon-Navaro (1997) \\
Acanthurus coeruleus & 0.0298 & 2.8778 & Bouchon-Navaro (1997) \\
\hline
\end{tabular}

Castelnau, 1855, Acanthurus chirurgus (Bloch, 1787) and Acanthurus coeruleus Bloch and Schneider, 1801. Herbivorous fishes present on the band-transects were identified, counted and their size estimated. Lengths were gathered in 5-cm size classes for fish under 20 and $10-\mathrm{cm}$ size classes for fish larger than $20 \mathrm{~cm}$. Fish biomass was then estimated using the median value of each class and weight-length relationships (WLR) available in the literature. The parameters $a$ and $b$ of the WLR used for each species are provided in Table 1.

Gut contents weighing and estimation of organic matter

All scarid and acanthurid species were collected on two reef flats (S2, S3) by spear fishing, except Scarus taeniopterus and $S$. vetula, as they lived mainly in marine protected areas and could not be captured. The ventral cavity of each fish speared was immediately injected with $10 \%$ buffered formalin in order to stop the digestion process, and the fishes were preserved in $10 \%$ formalin. After measuring the total length and weighting the fish, the digestive tract was removed and its content extracted. The gut content was dried to a constant weight at $80^{\circ} \mathrm{C}$. The digestive tract contains a ground mixture of sediments and algae. The proportion of organic matter present in the digestive tract was estimated by two different methods. For the Scaridae, the rates previously established by Randall (1967) were retained. For the Acanthuridae, the proportions of algae and sediment contained in the digestive tract were evaluated with a visual estimation derived from that of Jones (1968). Gut contents spread in Petri dishes were photographed with a stereomicroscope. A grid was superposed to the digitized photographs and the proportions of algae and sediment were estimated by pointintercept methods. After that, the algal and sediment rates were converted into volume by multiplying the obtained proportions by the densities of the sediment and the algae separately established.
Estimation of algal consumption by fish

Two different methods were used to evaluate the algal consumption by herbivorous reef fishes.

The first method (Method 1) consisted of building a curvilinear regression between the mass of dry organic matter found in the digestive tracts and the fish biomass. Scarus taeniopterus and $S$. vetula were assimilated to S. iserti and Sparisoma rubripinne, respectively as they have similar morphologies. The equation of the regression curve allowed calculating the quantity of algae ingested by the fishes according to their biomass (determined with WLR). The daily algal consumption was evaluated taking into account the data of Bardach (1961) and Ferreira et al. (1998) who considered that guts are filled thrice daily for herbivorous fishes in the Caribbean. This method allowed obtaining a global algal consumption estimation using simultaneously fish density on the reefs and algal consumption per species.

In order to confirm the values obtained by the previous technique, a second method (Method 2) was used. This method used the regression provided by van Rooij et al. (1998) calculating the organic carbon intake $(C)$ as a function of wet body weight ( $W$ in $g$ ) for herbivorous fishes:

daily $C$ intake $=0.0342 \times W^{0.816}$

with an algae carbon content fit to $40.5 \%$ (Bruggemann et al. 1994).

To test whether Method 1 and Method 2 provide similar results, a regression was carried out with Method 1 as a function of Method 2. Spearman' rank correlation test was used to test the correlation between both methods. Then, the proportionality between the two methods has been tested assuming that the regression slope $(\beta)$ was equal to 1 $\left(H_{\mathrm{o}}: \beta=1\right)$. Because assumptions of normality were not met, non-parametric ANOVAs based on ranks were used to analyse algal consumption. These tests were implemented with $\mathrm{R}$ software. The null hypothesis was the absence of 
effects of (i) used method to compute the algal consumption (ii) fish species (iii) MPA (iv) sites. After that, the Kruskal-Wallis one-way analysis of variance was used to compare the algal consumption between reef flats and reef slopes. Whenever a difference was found, multiple pairwise comparison tests were used to detect which sites were driving the observed differences.

\section{Estimation of the net algal turf production}

The measurements of net algal turf production were carried out in each site. For that purpose, floating plastic ribbons were settled at the bottom. A first experiment verified that the algal growth was approximately linear on a 1-month period. Then, every month, plastic ribbons were collected from the reef. Back to the laboratory, the algal turf was scrapped from the (known) surface of each ribbon and dried at $80^{\circ} \mathrm{C}$ until constant weight. Net algal turf production was so estimated by dry weight per surface and per month. This technique minimized sediment deposition and herbivory from urchins and gastropods but not fishes or crustaceans.

\section{Estimation of grazing rate}

The rates of fish grazing were estimated on three reef flats (S2, S3, S6), according to the dominant algal community which was determined using a line intercept method (Lucas and Seber 1977). In S2, fish bites were studied on the two dominant algal facies: turf either growing on coral rubbles or on the reef flat limestone $(29.0 \%$ of the benthic community) and Phaeophyta (Dictyota pulchella; 28.3\%). In S3, fish bites were recorded on algal turf (34.9\%), Phaeophyta (Dictyota pulchella; 20.1\%) and a facies of Halimeda (calcified Chlorophyta; 12.7\%). In S6, fish bites were only evaluated on algal turf $(62.5 \%)$, as it was the only algal facies to be present.

Grazing rates were estimated from observations made on areas of $1 \mathrm{~m}^{2}$ (delimited on the bottom by four small stones at each corner). Upon arrival at the study site, fish were given a few minutes to acclimatize to the settling of the stones and to the diver before timed observation began. During period of five minutes, the identity of herbivorous fishes, their size and the number of bites taken by each fish feeding in the area were recorded. During episodes of intensive feeding by schools, the number of fishes was recorded and the total number of bites estimated from the observation of a reduced number of individuals. On each site and in each algal facies, the feeding behaviour of fish was recorded during six replicated periods of five minutes on five different quadrats, which is a total of $150 \mathrm{~min}$ of observations for each type of algal facies.
The Kruskal-Wallis one-way analysis of variance was used to compare the grazing pressure between sites. Whenever a difference was found, multiple pairwise comparison tests were used to detect which sites were driving the observed differences. The affinity of the herbivorous fishes with the different algal facies was searched by factorial correspondence analysis (FCA).

\section{Results}

Fish consumption of algae

Proportions of organic and inorganic matter in the gut, derived from Randall (1967) for the Scaridae and determined in the present study for Acanthuridae, are given in Table 2. Acanthurus coeruleus ingest $100 \%$ of organic matter. For A. bahianus and A. chirurgus, the proportions were found to be respectively of 19.1 and $18.6 \%$. For the Scaridae, the proportions varied between 23.1 and $31.4 \%$. All the correlation coefficients associated with the linear regression (fish weight versus dry organic matter weight in the gut) were statistically significant (Spearman's rank correlation: $P<0.001$ for all the species; Table 3).

Total algal consumption values obtained using the two methods are presented in Table 4, as well as the algal consumption per species derived from METHOD 1. Values obtained from the two methods are linearly correlated (Fig. 2). Spearman's rank correlation coefficient is statistically significant $\left(r_{\mathrm{s}}=0.915 ; P<0.0001\right)$. Student's $t$ statistic showed that the regression slope $\beta$ was not different from 1 for the values of algal consumption of the global assemblage $\left(t=1.81 ; t_{0.05(2), 147}=1.976\right)$ as well as for the consumption by species ( $t$ always $<t_{0.05(2), 5}=$ 2.571). Results from the four-way ANOVA based on ranks

Table 2 Proportions of organic and inorganic matter in digestive tract contents of herbivorous fishes (in \%)

\begin{tabular}{lccc}
\hline Species & Organic matter & Inorganic matter & Source \\
\hline Acanthurus bahianus & 19.1 & 80.9 & $a$ \\
Acanthurus chirurgus & 18.6 & 81.4 & $a$ \\
Acanthurus coeruleus & 100 & 0 & $a$ \\
Scarus iserti & 24.6 & 75.4 & $b$ \\
Scarus taeniopterus & 26.4 & 73.6 & $b$ \\
Scarus vetula & 23.1 & 76.9 & $b$ \\
Sparisoma aurofrenatum & 24.5 & 75.5 & $b$ \\
Sparisoma chrysopterum & 30.5 & 69.5 & $b$ \\
Sparisoma rubripinne & 31.4 & 68.6 & $b$ \\
Sparisoma viride & 27.1 & 72.9 & $b$
\end{tabular}

$a$ Present study, $b$ Randall (1967) 
Table 3 Correlation coefficients associated with the linear regression between gut contents versus fish biomass, slope and intercept

$P$ value: $* * * P \leq 0.001$

- $P>0.05$

\begin{tabular}{llllr}
\hline Species & $r$ Coefficient & $\begin{array}{l}\text { Number of } \\
\text { individuals }\end{array}$ & Slope & Intercept \\
\hline Acanthurus bahianus & 0.6068 & 23 & $0.012^{* * *}$ & $0.565^{\bullet}$ \\
Acanthurus chirurgus & 0.8628 & 20 & $0.015^{* * *}$ & $0.442^{\bullet}$ \\
Acanthurus coeruleus & 0.9111 & 29 & $0.015^{* * *}$ & $-0.101^{\bullet}$ \\
Scarus iserti & 0.8600 & 27 & $0.009^{* * *}$ & $-0.014^{\bullet}$ \\
Sparisoma aurofrenatum & 0.7106 & 21 & $0.006^{* * *}$ & $0.053^{\bullet}$ \\
Sparisoma chrysopterum & 0.8726 & 20 & $0.008^{* * *}$ & $0.062^{\bullet}$ \\
Sparisoma rubripinne & 0.8797 & 21 & $0.001^{* * *}$ & $0.175^{\bullet}$ \\
Sparisoma viride & 0.9018 & 21 & $0.011^{* * *}$ & $-0.313^{\bullet}$ \\
\hline
\end{tabular}

Table 4 Daily algal consumption rates $\left(\mathrm{g} \mathrm{m}^{-2}\right.$ days $\left.^{-1}\right)$ obtained for each species in each site with Method 1 and total algal consumption of the whole herbivorous fish assemblage obtained with both methods

\begin{tabular}{|c|c|c|c|c|c|c|c|c|c|c|c|c|}
\hline & $\mathrm{S} 1$ & $\mathrm{~S} 2$ & $\mathrm{~S} 3$ & S4 & S5 & S6 & S7 & S8 & S9 & $\mathrm{S} 10$ & $\mathrm{~S} 11$ & $\begin{array}{l}\text { Total per } \\
\text { species }\end{array}$ \\
\hline Acanthurus bahianus & 0.19 & 0.06 & 0.14 & 0.34 & 0.93 & 0.43 & 0.07 & 0.16 & 0.11 & 0.16 & 0.83 & 3.43 \\
\hline Acanthurus chirurgus & 0.10 & 0 & 0.01 & 0.54 & 0.25 & 0.01 & 0.01 & 0.01 & 0 & 0.33 & 0.05 & 1.30 \\
\hline Acanthurus coeruleus & 0.25 & 0.7 & 0.07 & 0.45 & 0.79 & 0.42 & 0.07 & 0.07 & 0.05 & 0.60 & 0.06 & 3.53 \\
\hline Scarus iserti & 0.06 & 0.12 & 0.06 & 0.13 & 0.51 & 0.06 & 0 & 0.12 & 0.26 & 0.11 & 0.01 & 1.44 \\
\hline Scarus taeniopterus & 0.01 & 0.02 & 0.04 & 0 & 0.03 & 0.32 & 0.08 & 0.06 & 0.20 & 0.04 & 0 & 0.80 \\
\hline Scarus vetula & 0.02 & 0 & 0 & 0 & 0.01 & 0.55 & 0.12 & 0.01 & 0 & 0.01 & 0 & 0.72 \\
\hline Sparisoma aurofrenatum & 0.01 & 0 & 0.01 & 0.02 & 0.03 & 0.08 & 0.12 & 0.19 & 0.35 & 0.11 & 0.14 & 1.05 \\
\hline Sparisoma chrysopterum & 0.01 & 0.03 & 0.03 & 0.05 & 0.05 & 0.06 & 0.01 & 0 & 0 & 0.01 & 0 & 0.25 \\
\hline Sparisoma rubripinne & 0.01 & 0.03 & 0.02 & 0.17 & 0.04 & 0.08 & 0.07 & 0.05 & 0 & 0 & 0.15 & 0.62 \\
\hline Sparisoma viride & 0.02 & 0.02 & 0.02 & 0.04 & 0.16 & 0.53 & 0.57 & 0.51 & 0.34 & 0.11 & 0.01 & 2.33 \\
\hline \multicolumn{13}{|l|}{ Total per site } \\
\hline Method 1 & 0.68 & 0.98 & 0.4 & 1.75 & 2.79 & 2.54 & 1.11 & 1.18 & 1.32 & 1.49 & 1.24 & \\
\hline Method 2 & 0.81 & 1.09 & 0.67 & 2.05 & 3.24 & 2.77 & 1.14 & 1.61 & 1.77 & 1.56 & 1.36 & \\
\hline
\end{tabular}

Sites: $\mathrm{S} 1-\mathrm{S} 11$

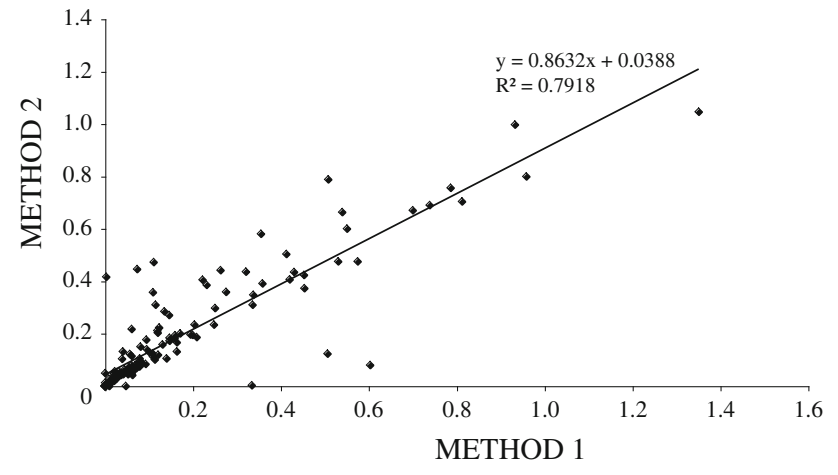

Fig. 2 Algal consumption values $\left(\mathrm{g} \mathrm{m}^{-2}\right.$ days $\left.^{-1}\right)$ regressed with Method 1 versus Method 2

showed that the estimation of algal consumption was not influenced by the method used for its computation $\left(F_{(1,140)}=2.250, P=0.136\right)$.

Concerning the studied reef sites, results from fourway ANOVA on ranks revealed that, on the whole, the algal consumption was influenced by the protection status of the sites $\left(F_{(1,140)}=13.179, P<0.001\right)$ and by the type of sites (reef flats or reef slopes) $\left(F_{(1,140)}=4.155\right.$, $P=0.043)$. A Kruskall-Wallis test was used to detail this result between reef flats and reef slopes. Its results showed that algal consumption is significantly different among the different reef flats $(P$-value $=0.04)$. A multiple pairwise comparison test revealed that this difference was mainly due to sites S5 and S6 (MPA), which presented a high level of algal consumption (2.8 and $2.5 \mathrm{~g} \mathrm{~m}^{-2}$ days $^{-1}$ ) compared to $\mathrm{S} 1, \mathrm{~S} 2$ and $\mathrm{S} 3$ where the consumption values were low (respectively $0.7 ; 1$ and $0.4 \mathrm{~g} \mathrm{~m}^{-2}$ days $^{-1}$ ). These differences were due to fish densities (Table 5) which varied between sites. Algal consumption was more important in S5 and S6 as herbivorous fishes were well represented in biomass (Table 5). Results for S1, S2 and S3 were closer because of their equivalent herbivore assemblages in terms of abundance. A Kruskall-Wallis test comparing the reef slopes (S7-S11) showed no significant difference 


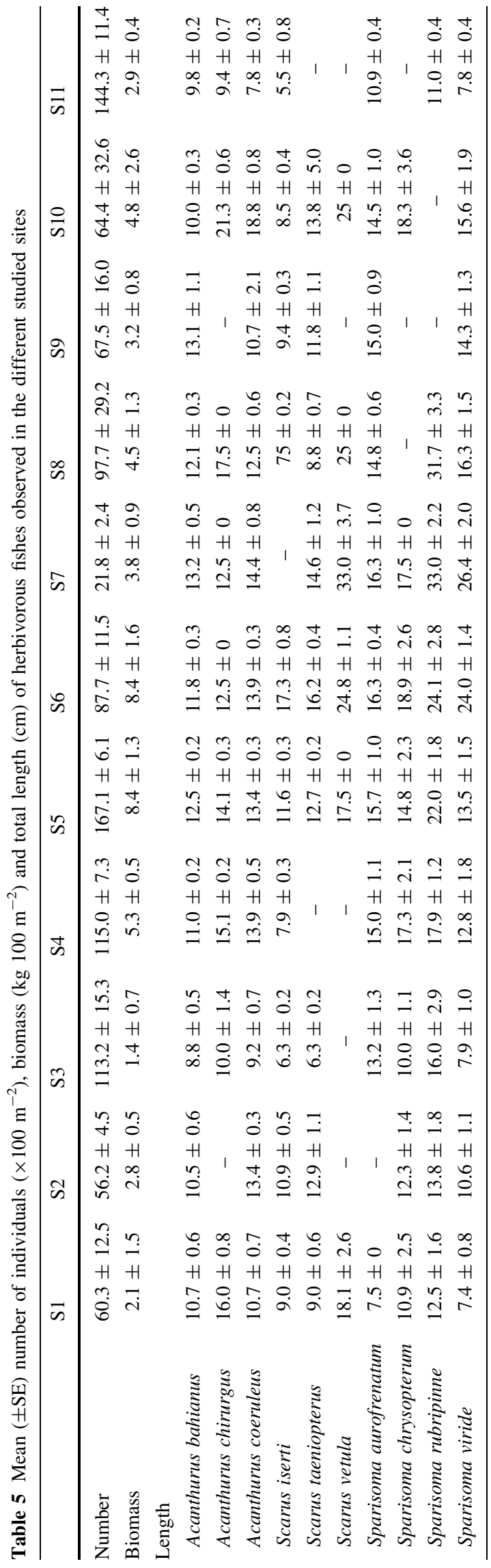

$(P$-value $=0.88)$ in the algal consumption that is relatively stable whatever the localization.

Finally, results from four-way ANOVA on ranks pointed out that the algal consumption was different according to the fish species considered $\left(F_{(9,140)}=13.514\right.$, $P<0.001)$. Examination of Table 4 shows that Acanthurus bahianus, A. coeruleus and Sparisoma viride exerted a high consumer pressure $\left(2.6 ; 3.5\right.$, and $2.32 \mathrm{~g} \mathrm{~m}^{-2}$ days ${ }^{-1}$, respectively).

Net algal turf production and algal gross production

Net algal turf production was relatively stable between the different reef flats and varied between 0.6 and $1.29 \mathrm{~g} \mathrm{~m}^{-2}$ days $^{-1}$ (Table 6). On the reef slopes (S7-S10), values were lower $\left(0.3-0.8 \mathrm{~g} \mathrm{~m}^{-2}\right.$ days $\left.^{-1}\right)$. To determine the daily algal gross production on the studied coral reefs, net algal turf production was added to herbivorous fish consumption (Table 6). Algal gross production varied between 1.48 and $3.78 \mathrm{~g} \mathrm{~m}^{-2}$ days $^{-1}$ on the reef flats with maximum values observed in S5 and S6. On the reef slopes, algal gross production varied between 1.41 and $1.98 \mathrm{~g} \mathrm{~m}^{-2}$ days $^{-1}$.

\section{Estimation of grazing pressure}

\section{Preferred algal facies}

The grazing pressure of herbivorous fishes was measured on four facies of algae in three sites, S2, S3, and S6.

At S3, three facies of algae were compared. A KruskallWallis test revealed a significant difference between the grazing pressures among the different algal facies when considering the number of bites $(P<0.0001)$. Multiple pairwise comparison tests show that the differences were due to the Phaeophyta facies which is the less grazed. The herbivory pressure was not statistically significant between the other algal facies (algal turf growing on coral rubble and on limestone).

At site S2, four algal facies were present: turf on limestone, turf on rubble, Dictyota and Halimeda. A Kruskal-Wallis test revealed a significant difference between the grazing pressure among the four algal facies $(P=0.001)$. Pairwise comparison tests showed that this difference could be attributed again to Dictyota, less grazed by the fishes.

Figure 3 represents the number of bites counted in the three sites. The rates of fish bites varied between 6,936 and 70,545 bites $^{-2}$ days $^{-1}$ with the lowest grazing rate recorded on Dictyota in S3 and the highest on coral rubble in S2. In S2 and S3, the grazing rate was the greatest on the turf zones and was lower on the macroalgae. In S6 (MPA), 
Table 6 Algal consumption by herbivorous fishes, algal turf net production, daily algal gross production $\left(\mathrm{g} \mathrm{m}^{-2}\right.$ days $\left.^{-1}\right)$ and algal consumption as a percentage of gross production $(\%)$ in each site

\begin{tabular}{|c|c|c|c|c|c|c|c|c|c|c|c|}
\hline & S1 & $\mathrm{S} 2$ & S3 & S4 & S5 & S6 & S7 & S8 & S9 & S10 & S11 \\
\hline Algal consumption $\left(\mathrm{g} \mathrm{m}^{-2}\right.$ days $\left.^{-1}\right)$ & 0.68 & 0.98 & 0.4 & 1.75 & 2.79 & 2.54 & 1.11 & 1.18 & 1.32 & 1.49 & 1.24 \\
\hline Algal turf net production $\left(\mathrm{g} \mathrm{m}^{-2}\right.$ days $\left.^{-1}\right)$ & 0.80 & 1.15 & 1.29 & 0.60 & 1.00 & 1.24 & 0.30 & 0.80 & 0.50 & 0.30 & - \\
\hline Daily algal gross production $\left(\mathrm{g} \mathrm{m}^{-2}\right.$ days $\left.^{-1}\right)$ & 1.48 & 2.13 & 1.69 & 2.35 & 3.79 & 3.78 & 1.41 & 1.98 & 1.82 & 1.79 & - \\
\hline Consumption/gross production (\%) & 45.9 & 46 & 23.7 & 74.5 & 73.6 & 67.2 & 78.7 & 59.6 & 72.5 & 83 & - \\
\hline
\end{tabular}

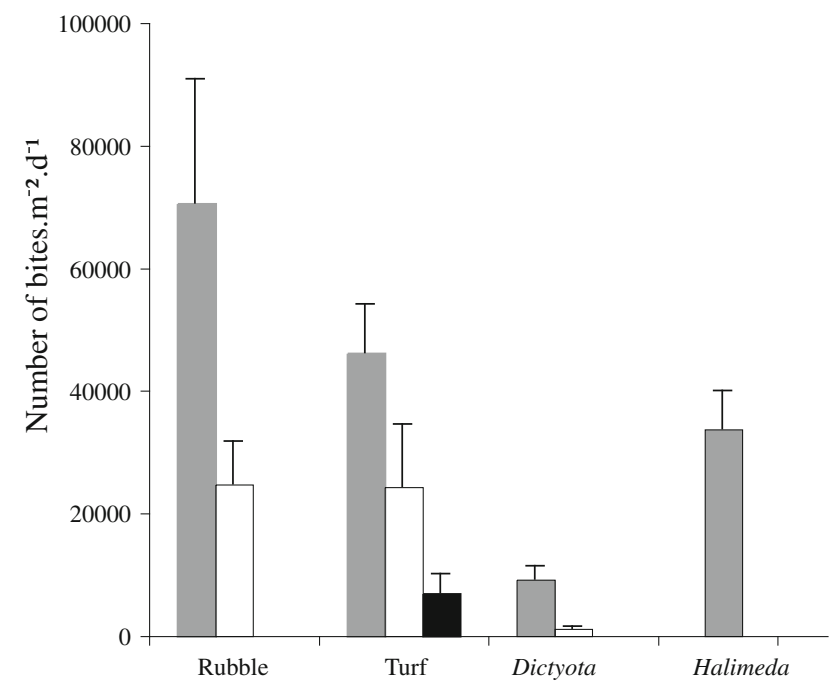

Fig. 3 Daily number of fish bites $( \pm \mathrm{SE})$ per $100 \mathrm{~m}^{-2}$ in $\mathrm{S} 2$ (grey bars), in S3 (white bars) and in S6 (dark bar)

only algal turf was present and grazing rate was lower that in the other sites.

\section{Species preferences}

In order to highlight peculiar affinities between the herbivorous species and the different facies of algae, a factorial correspondence analysis (FCA) was carried out crossing the number of bites per species and the different algal facies (Fig. 4). The first two axes explain $97 \%$ of the variance of the data with $76 \%$ on axis 1 and $21 \%$ on axis 2 . The first axis opposes the algal turf growing on limestone to the three other facies. The species contributing most to this axis are Acanthurus coeruleus and Sparisoma aurofrenatum which graze preferentially on algal turf. On the other side of the axis, Sparisoma rubripinne is more linked to the Halimeda facies and to the turf growing on coral rubble. Axis 2 opposes Dictyota to Halimeda, underlining a preferential distribution of Acanthurus bahianus on Phaeophyta and of Sparisoma viride on the Halimeda facies. The feeding preferences of the other species are more eclectic.

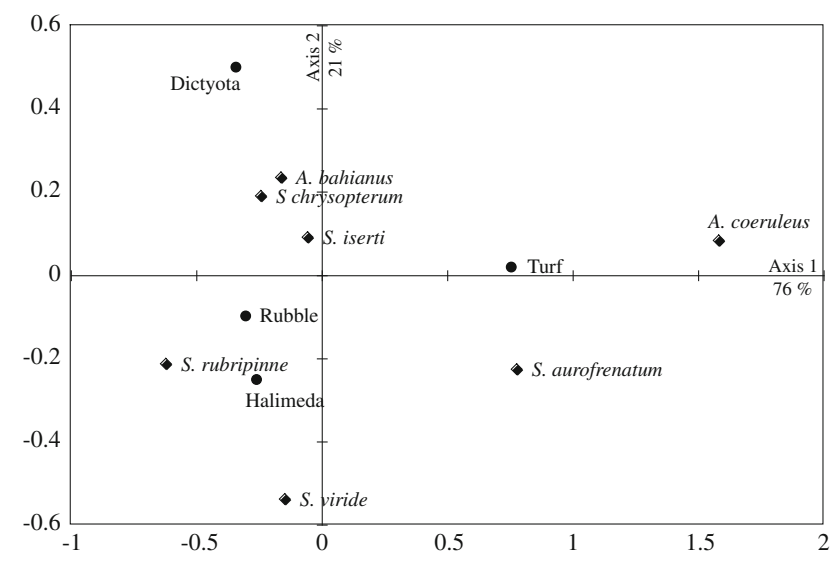

Fig. 4 Results of the factorial correspondence analysis crossing the number of bites per species and the different algal facies

\section{Discussion and conclusions}

Algal consumption and production

The algal consumption obtained in the present work (between 0.68 and $2.79 \mathrm{~g} \mathrm{~m}^{-2}$ days $^{-1}$ ) are in accordance with the values reported by other authors (Table 7) and particularly with the most recent study of Paddack et al. (2006). Contrarily, the values of production estimated in the present study are relatively low compared to those found by other authors. Indeed, when estimating the algal production in the present work, herbivorous fishes, urchins and gastropods were able to graze on the experimental device. The net algal turf production might be consequently under-estimated. When considering fish algal consumption and adding it to the net algal turf production in order to obtain a gross algal production, the values estimated in the present study remain low compared to those found in previous studies (Table 7).

The comparison between algal consumption and production permitted to highlight the quantitative regulation of algae by herbivorous fishes. Thus, on non-protected and heavily fished coral reefs, although the herbivorous fishes are numerically abundant, the small sizes reached by these fishes did not allow them to regulate the algal production. Once epilithic algal turf grows, propagules of macroalgae 
Table 7 Values of algal consumption by different kinds of herbivores and algal production on several reefs

\begin{tabular}{|c|c|c|c|c|}
\hline \multirow[t]{2}{*}{ Location } & \multirow[t]{2}{*}{ Authors } & \multirow{2}{*}{$\begin{array}{l}\text { Algal production } \\
\left(\mathrm{g} \text { of algae } \mathrm{m}^{-2} \text { days }^{-1}\right)\end{array}$} & \multicolumn{2}{|l|}{ Consumption } \\
\hline & & & Species & $\mathrm{g}$ of algae $\mathrm{m}^{-2}$ days $^{-1}$ \\
\hline Guadeloupe & Present study & $1.4-3.8$ & Herbivorous fishes & $0.4-2.5$ \\
\hline \multirow[t]{2}{*}{ Bonaire } & van Rooij et al. (1998) & 4.25 & Herbivorous fishes & 4.3 \\
\hline & & & Urchins & 0.5 \\
\hline \multirow[t]{2}{*}{ Virgin islands } & Carpenter (1986) & $5.7-7.1$ & Herbivorous fishes & $5-8.2$ \\
\hline & Carpenter (1985) & $5.2-7.7$ & & \\
\hline \multirow[t]{2}{*}{ Florida } & Paddack et al. (2006) & 2.6 & Sparisoma viride & 0.4 \\
\hline & & & Herbivorous fishes & 1.7 \\
\hline \multirow[t]{9}{*}{ Australia } & Polunin and Klumpp (1992) & $4.4-5.3$ & Amphipod & $78.7-90.7\left(\times 10^{-3}\right)$ \\
\hline & & & Copepod & $1.85-2\left(\times 10^{-3}\right)$ \\
\hline & & & Other crustacean & $84.6-98.5\left(\times 10^{-3}\right)$ \\
\hline & & & Mollusc & $41.4-47.5\left(\times 10^{-3}\right)$ \\
\hline & & & Polychete & $64.4-74.1\left(\times 10^{-3}\right)$ \\
\hline & & & Gasteropod & $14.9-18.1\left(\times 10^{-3}\right)$ \\
\hline & & & Acanthurus lineatus & $1.57-2.16$ \\
\hline & Klumpp and McKinnon (1989) & $2.75-6.2$ & & \\
\hline & Russ (2003) & $0.5-2.9$ & & \\
\hline Marshall islands & Bakus (1967) & $1.6-5.3$ & & \\
\hline
\end{tabular}

can develop until their adult size when they become resistant to herbivory.

In marine protected areas, where fishes reach large sizes (Table 5; Hawkins and Roberts 2003), herbivorous fishes consume a larger part of the algal production. On these reefs, the herbivorous populations are almost intact and can better ensure their role of regulation on algae than outside marine reserves. On the protected reefs of Bonaire, van Rooij et al. (1998) established that the primary production of algae was completely consumed by herbivores. Carpenter (1986) also observed this phenomenon in the Virgin Islands and argued that herbivores are able to take $100 \%$ of the daily algal production. For Hatcher (1981) in Australia, herbivores can consume between 20 and $70 \%$ of the algal production on the reefs.

The choice of a stomach repletion rate of three times per day food intake may have an influence on the estimated consumption. This value varies among authors. In French Polynesia, Polunin et al. (1995) determined fish food intakes between 1.7 and 13.8 times per day according to the considered species and using stomach repletion rates. Polunin and Klumpp (1992) in Australia determined that herbivorous fishes feed 10.5 times per day in summer and 5.5 times per day in winter using fish feeding rate. For Hatcher (1981) in Australia also, fish daily feeding rate varies between 2.5 and 8.4 with a mean of 5.2 times per day. In the Caribbean, Gygi (1975) determined that Sparisoma viride filled up its stomach one time per day, whereas according to Bruggemann et al. (1996), the same species filled up its stomach ten times a day based on species feeding rates. Ferreira et al. (1998), based on gut turnover, have determined that Scaridae feed between 2.4 and 2.7 times per day and approximately three times per day for the Acanthuridae. Comparison between the results of the present study and those obtained with the estimation of van Rooij et al. (1998) reveals that our estimation was probably appropriate for the Caribbean.

Finally, this study shows that the three species of Acanthuridae (Acanthurus bahianus, A. chirurgus and A. coeruleus) and Sparisoma viride are the herbivores ingesting the most important quantity of algae. Two hypotheses can be formulated to explain this fact. First, these four species could have a food digestion lower than the other species and consequently they would have to ingest more food than the other species. A second hypothesis would be that the growth of these species is faster than those of other species and so they have to consume more food to sustain their higher metabolism. Randall (1962) showed that the monthly growth of Acanthurus bahianus is $2.7 \mathrm{~mm}$, that of A. chirurgus is $2.3 \mathrm{~mm}$, that of $A$. coeruleus $1.3 \mathrm{~mm}$ and that of Sparisoma viride varies between 3.5 and $7.7 \mathrm{~mm}$. Other scarid species have more important growth rates (for example between 11 and $18 \mathrm{~mm}$ per month for Scarus vetula) and nevertheless they ingest a lower quantity of organic matter. These results tend to confirm that the first hypothesis would be the most likely.

Feeding rate

The rates of fish bites obtained in the present work (between 6,936 and 70,545 bites $\mathrm{m}^{-2}$ days $^{-1}$ ) are in accordance with 
the values reported by other authors. Carpenter (1986) found in St. Croix (U.S. Virgin Islands) that scarid fishes are able to give between 20,000 and $156,000{\text { bites } \mathrm{m}^{-2} \text { days }}^{-1}$ according to the period of the year. For Steneck (1983), the mean number of bites on a reef is 5,000 bites $\mathrm{m}^{-2} \mathrm{~h}^{-1}$, that is to say, 60,000 bites $\mathrm{m}^{-2}$ days ${ }^{-1}$.

The results of the present work also revealed that herbivorous fishes feed preferentially on certain type of algae. Algal turf is the favourite food source for herbivorous fishes. Such preferences have already been noted for Caribbean herbivorous fishes (Bruggemann et al. 1994; Paddack et al. 2006) as well as for herbivorous fishes in general (Steneck 1988; Bellwood and Choat 1990). Van Alstyne et al. (1999) reported that algal turf, partly constituted by young shoots of macroalgae, is the most consumed because these shoots contain higher nitrogen concentration in their tissues than old algae. This phenomenon may influence the food choice of herbivorous fishes seeking protidic complements (Mattson 1980). Moreover, algal turf is easily digested and has a higher energetic and proteinic value than macroalgae (Bruggemann et al. 1994).

Conversely, herbivorous fishes avoid brown macroalgae, mainly composed of Dictyota spp. in the studied reefs. This phenomenon can be explained in two ways. First, the presence of repulsive or toxic molecules renders macroalgae less palatable and digestive to herbivorous fishes particularly for the Dictyota algae that would be the less consumed by herbivorous fishes because they contain diterpenoids that protect them from fish and sea urchins herbivory (Hay et al. 1987; Barbosa et al. 2004). The predominance of this type of algae on the studied nonprotected reefs may explain why the herbivory rate is very low. However, some bites have been observed on these macroalgae. Fishes may graze the epiphytic microalgae that grow on the macroalgae thallus. Secondly, the thallus calcification of some algae would prevent fishes from feeding on them (Ochavillo et al. 1992). This hypothesis does not seem to correspond to the results of the present study as the number of bites observed on Halimeda spp. is comprised between those observed on algal turf and those on Phaeophyta. According to Schupp and Paul (1994), surgeonfishes avoid grazing on algae containing calcium carbonate like Halimeda spp. Steneck (1988) argued that Acanthuridae are not able to crunch on calcified or incrusting algae because of their dentition, whereas scarids can ingest all algal types. So, the Scaridae would be the only fishes that sometimes consume Halimeda spp., such as Sparisoma viride in the present study and that of Overholtzer and Motta (1999).

Finally, the grazing rate has been found to be highly correlated with herbivorous fish abundance like in the studies of Lewis and Wainwright (1985) and Carpenter
(1986). The reefs presenting the higher grazing pressure harbour the highest abundance of herbivorous fishes but the lowest biomass. Carpenter (1986, 1988, 1990) explained this phenomenon as the majority of herbivores was juvenile scarids that have a small mouth. They produce a high number of bites which only remove small quantities of algae. This can explain why even when herbivorous fishes present high number of individuals, macroalgae can cover large parts of the reef. Algal turf develops into more enduring macroalgae, preventing the recovery of the reef into its previous coral dominated state (Szmant 2002). In marine protected areas, although the rate of fish bites is the lowest, macroalgae are absent. In fact, fishes are of large size in protected areas. They do few bites but efficient ones preventing phase shift by keeping algae cropped down.

This study demonstrated that the role of herbivorous fishes in promoting reef recovery and resilience is likely to depend not only on their feeding preferences but also on their numerical abundance and on their biomass. Fish abundance and mostly fish biomass might be expected to increase when algal production increased in order to control macroalgal proliferation. However, overfishing prevents the establishment of such a feed back control except in MPA where the protection status renders algal regulation possible by maintaining healthy herbivorous fish assemblages.

Acknowledgments Thanks are expressed to the Réserve Marine du Grand Cul-de-Sac Marin for their authorisation to work in the protected areas. We are grateful to Prof. David Mouillot from the Université Montpellier 2 and to Anik Brind'Amour from the IFREMER for their helpful advices and assistance about data processing. We wish to thank two anonymous reviewers who provided valuable comments on an earlier version of this paper.

\section{References}

Bakus GJ (1967) The feeding habits of fishes and primary production at Eniwetok, Marshall Islands. Micronesica 3:135-149

Barbosa JP, Teixeira VL, Pereira RC (2004) A dolabellane diterpene from the brown alga Dictyota pfaffi as chemical defense against herbivores. Bot Mar 47:147-151

Bardach JE (1961) Transport of calcareous fragments by reef fishes. Science 133:98-99

Bellwood DR, Choat JH (1990) A functional analysis of grazing in parrotfishes (family Scaridae): the ecological implications. Environ Biol Fish 28:189-214

Bellwood DR, Hughes TP, Folke C et al (2004) Confronting the coral crisis. Nature 429:827-833

Bellwood DR, Hoey AS, Ackerman JL et al (2006) Coral bleaching, reef fish community phase shifts and the resilience of coral reefs. Glob Chang Biol 12:1-8

Bohnsack JE, Harper DE (1988) Length-weight relationships of selected marine reef fishes from Southern United States and the Caribbean. NOAA Tech Memo NMFS-SEFC-215

Bouchon C, Laborel J (1986) Coral reefs of Martinique Island. Ann Inst Oceanogr 62:199-237 
Bouchon C, Laborel J (1990) Les peuplements coralliens du Grand Cul-de-Sac marin de Guadeloupe (Antilles françaises). Ann Inst Oceanogr 66:19-36

Bouchon C, Portillo P, Bouchon-Navaro Y et al (2008a) Status of the coral reefs of the Lesser Antilles in 2008: the French West Indies, the Netherlands Antilles, Anguilla, Antigua and Barbuda, Grenada, Trinidad and Tobago. In: Wilkinson C et al (eds) Status of coral reefs of the world Vol. 3. Australian Institute of Marine Sciences, Australia, pp 265-280

Bouchon C, Portillo P, Bouchon-Navaro Y et al (2008b) Status of coral reefs in the Lesser Antilles after the 2005 coral bleaching event. In: Wilkinson C, Souter D et al (eds) Status of Caribbean coral reefs after bleaching and hurricanes in 2005. Global Coral Reef Monitoring Network and Reef and Rainforest Research Center, Townsville, pp 85-104

Bouchon-Navaro Y (1997) Les peuplements ichtyologiques récifaux des Antilles. Distribution spatiale et dynamique temporelle. $\mathrm{PhD}$ Thesis, Université Antilles Guyane

Bruggemann JH, Begeman J, Bosma E et al (1994) Foraging by the stoplight parrotfish Sparisoma viride. II. Intake and assimilation of food, protein, and energy. Mar Ecol Prog Ser 106:57-71

Bruggemann JH, van Kessel AM, van Rooij JM et al (1996) Bioerosion and sediment ingestion by the Caribbean parrotfish Scarus vetula and Sparisoma viride: implications of fish size, feeding mode and habitat use. Mar Ecol Prog Ser 134:59-71

Carpenter RC (1985) Relationships between primary production and irradiance in coral reef algal communities. Limnol Oceanogr 30:784-793

Carpenter RC (1986) Partitioning herbivory and its effects on coral reef algal communities. Ecol Monogr 56:345-363

Carpenter RC (1988) Mass mortality of a Caribbean sea urchin: immediate effects on community metabolism and other herbivores. Proc Natl Acad Sci U S A 85:511-514

Carpenter RC (1990) Mass mortality of Diadema antillarum II. Effects on population densities and grazing intensity of parrotfishes and surgeonfishes. Mar Biol 104:79-86

Chauvaud S, Bouchon C, Manière R (1998) Remote sensing techniques adapted to high resolution mapping of tropical coastal marine ecosystems (coral reefs, seagrass beds and mangrove). Int J Remote Sens 19:3625-3639

Chauvaud S, Bouchon C, Manière R (2001) Cartographie des biocénoses marines de Guadeloupe à partir des données SPOT (récifs coralliens, phanérogames marines, mangroves). Oceanol Acta 24:S3-S16

Claro R, García-Arteaga JP (1994) Crecimiento. In: Claro R (ed) Ecología de los peces marinos de Cuba. Centro de Investigaciones de Quintana Roo, Mexico, pp 321-402

Ferreira CEL, Peret AC, Coutinho R (1998) Seasonal grazing rates and food processing by tropical herbivorous fishes. J Fish Biol 53:222-235

Gardner TA, Côté IM, Gill JA et al (2003) Long-term region-wide declines on Caribbean corals. Science 301:958-960

Gygi RA (1975) Sparisoma viride (Bonnaterre), the stoplight parrotfish, a major sediment producer on coral reefs of Bermuda. Eclogae Geol Helv 68:327-359

Hatcher BG (1981) The interaction between grazing organisms and the epilithic algal community of a coral reef: a quantitative assessment. Proc 4th Intl Coral Reef Symp 2:515-524

Hawkins JP, Roberts CM (2003) Effects of fishing on sex-changing Caribbean parrotfishes. Biol Conserv 115:213-226

Hay ME, Fenical W, Gustafson K (1987) Chemical defense against diverse coral-reef herbivores. Ecology 68:1581-1591

Hughes TP (1994) Catastrophes, phases shifts, and large-scale degradation of a Caribbean coral reef. Science 265:1547-1551

Hughes TP, Baird AH, Bellwood DR et al (2003) Climate change, human impacts, and the resilience of coral reefs. Science 301:929-933
Hughes TP, Rodrigues MJ, Bellwood DR et al (2007) Phase shifts, herbivory and the resilience of coral reefs to climate change. Curr Biol 17:1-16

Jackson JBC, Kirby MX, Berger WH et al (2001) Historical overfishing and the recent collapse of coastal ecosystems. Science 293:629-638

Jones RS (1968) Ecological relationships in Hawaiian and Johnston Island Acanthuridae (Surgeonfishes). Micronesica 4:309-361

Klumpp DW, McKinnon AD (1989) Temporal and spatial patterns in primary production of a coral-reef epilithic algal community. J Exp Mar Biol Ecol 131:1-22

Lewis SM, Wainwright PC (1985) Herbivore abundance and grazing intensity on a caribbean coral reef. J Exp Mar Biol Ecol 87:215-228

Lucas HA, Seber GAF (1977) Estimating coverage and particle density using the line intercept method. Biometrika 64:618-622

Mattson WJ (1980) Herbivory in relation to plant nitrogen content. Annu Rev Ecol Syst 11:119-161

Mumby PJ (2006) The impact of exploiting grazers (Scaridae) on the dynamics of Caribbean coral reefs. Ecol Appl 16:747-769

Mumby PJ, Dahlgren CP, Harborne AR et al (2006) Fishing, trophic cascades, and the process of grazing on coral reefs. Science 311:98-101

Ochavillo DG, Dixon PI, Alino PM (1992) The daily food ration of parrotfishes in the fringing reefs of Bolinao Pangasinan, Northwestern Philippines. Proc 7th Int Coral Reef Symp 2:927-933

Overholtzer KL, Motta PJ (1999) Comparative resource use by juvenile parrotfishes in the Florida Keys. Mar Ecol Prog Ser 177:177-187

Paddack MJ, Cowen RK, Sponaugle S (2006) Grazing pressure of herbivorous coral reef fishes on low coral-cover reefs. Coral Reefs 25:461-472

Pandolfi JM, Bradbury RH, Sala E et al (2003) Global trajectories of the long-term decline of coral reef ecosystems. Science 301:955-958

Pandolfi JM, Jackson JBC, Baron N et al (2005) Are US coral reefs on the slippery slope to slime? Science 307:1725-1727

Polunin NVC, Klumpp DW (1992) Algal food supply and grazer demand in a very productive coral-reef zone. J Exp Mar Biol Ecol 164:1-15

Polunin NVC, Harmelin-Vivien ML, Galzin R (1995) Contrasts in algal food processing among five herbivorous coral-reef fishes. J Fish Biol 47:455-465

Randall JE (1962) Tagging reef fishes in the Virgin Islands. Proc GCFI 14:201-241

Randall JE (1967) Food habits of reef fishes of the West Indies. Stud Trop Oceanogr 5:665-847

Russ GR (2003) Grazer biomass correlates more strongly with production than with biomass of algal turfs on coral reef. Coral Reefs 22:63-67

Schupp PJ, Paul VJ (1994) Calcium carbonate and secondary metabolites in tropical seaweeds: variable effects on herbivorous fishes. Ecology 75:1172-1185

Steneck RS (1983) Quantifying herbivory on coral reefs: just scratching the surface and still biting off more than we can chew. In: Reaka ML (ed) The ecology of deep and shallow coral reefs. Symposia series for undersea research, Office of undersea research, NOAA, Rockville, pp 103-110

Steneck RS (1988) Herbivory on coral reefs: a synthesis. Proc 6th Int Coral Reef Symp 1:37-49

Szmant A (2002) Nutrient enrichment on coral reefs: is it a major cause of coral reef decline? Estuaries 25:743-766

Van Alstyne KL, Ehlig JM, Whitman SL (1999) Feeding preferences for juvenile and adult algae depend on algal stage and herbivore species. Mar Ecol Prog Ser 180:179-185

van Rooij JM, Videler JJ, Bruggemann JH (1998) High biomass and production but low energy transfer efficiency of Caribbean parrotfish: implications for trophic models of coral reefs. J Fish Biol 53:154-178 